IRSH 54 (2009), pp. 429-458 doi:I0.I0I7/So020859009990332

(C) 2009 Internationaal Instituut voor Sociale Geschiedenis

\title{
Finding Captain Swing: Protest, Parish Relations, and the State of the Public Mind in I 830
}

\author{
PETER JONES \\ Department of History, Oxford Brookes University
}

E-mail: dr_jones_i@hotmail.com

\begin{abstract}
Summary: From the i950s to the i970s, the study of English popular protest was dominated by the work of Eric Hobsbawm, George Rudé, and Edward Thompson, and it is no exaggeration to suggest that their combined approach became the standard against which all subsequent work was judged. It was seminal, innovative and crucial to the emergence of a new "history from below". But it was, to a degree, also formulaic: it relied on a trusted framework that historians have since struggled to deviate from. Through a detailed investigation of a set of disturbances in Berkshire, England during the so-called "Swing riots", this essay seeks to demonstrate that a continued reliance on this model can be seen to have stifled a more nuanced understanding of particular "moments" of protest in the locality, and in doing so it places a much greater emphasis on local social - and in particular, parochial - relations than has previously been the case. In sum, within the context of late-Hanoverian popular protest, this essay is a plea for a new "history from within" to supplement the (now venerable) tradition of "history from below".
\end{abstract}

\section{INTRODUCTION}

This year sees the fortieth anniversary of the publication of Eric Hobsbawm and George Rudé's wide-ranging study of agrarian protest, Captain Swing. ${ }^{\mathrm{I}}$ It would not be unfair to suggest that in the intervening years, while a few historians have tinkered around the edges of the methodological and historiographical model it established, the template itself remains largely unmolested. ${ }^{2}$ But forty years is a long time in social history, and there are a number of reasons why this template would benefit from a fundamental reassessment. On the one hand, recent research suggests that Hobsbawm

I. E.J. Hobsbawm and G. Rudé, Captain Swing (London, I969).

2. One notable exception to this rule is that of Carl Griffin, whose work on Swing explicitly sets out to place "outbreaks of 'Swing' into the context of local employment and social relations". See especially C. Griffin, “'There Was No Law to Punish That Offence': Reassessing 'Captain Swing': Rural Luddism in East Kent, I830-3I”, Southern History, 22 (2000), pp. I3 I-163. 
and Rudé may have seriously underestimated the scale of the disturbances, not only in terms of the number of crowd actions and arson attacks and their geographical spread, but in terms of the time period over which they took place; ${ }^{3}$ on the other, fundamental questions remain over the methodology they employed, and these questions grow more insistent with each passing year.

In describing and analysing the events of 1830 , Hobsbawm and Rudé relied on a model of popular protest that owed much to their own previous work, as well as to the earlier work of the Hammonds on "the last labourers' revolt". ${ }^{4}$ This approach can best be described as a reliance on brief narrative accounts or "case studies" of various disturbances taken from a range of official, semi-official, and anecdotal sources, alongside a discussion of the wider structural (economic, political, and statutory) framework within which they took place. While I certainly have no wish to demean or caricature their work, nonetheless I believe that this brief summary accurately reflects their approach in the most general terms. And I would go further, to suggest that this simple model has become the standard for proponents of "protest studies" right up to the present day, even providing the working template for the godfather of the discipline, E.P. (Edward) Thompson. Notwithstanding the fact that he pioneered the most subtly nuanced approach to popular protest in his I97 I Past and Present article, "The Moral Economy of the English Crowd in the Eighteenth Century", his work was largely distinguished by its "anthropological" approach, and the wonderfully realized ambition to place protesters themselves at centre stage, as the main actors in a drama of their own making. In other words, neither in his original article, nor in his subsequent work, did Thompson fundamentally challenge the model of "case study" alongside "structural/statutory framework" for studying popular protest. ${ }^{\text {s }}$

3. Ibid., p. I 40. A recent project by the Family and Community Historical Research Society, using the combined resources of its members and casting its net across the whole of England, claims to have turned up over 3,300 individual "Swing" incidents between I 830 and I 832 , more than double the number recorded by Hobsbawm and Rudé. See M. Holland (ed.), Swing Unmasked: The Agricultural Riots of 1830 to 1832 and Their Wider Implications (Milton Keynes, 2005), Appendix I, and the accompanying CD-Rom, Swing Unmasked (Milton Keynes, 2005).

4. J.L. and B. Hammond, The Village Labourer, I760-I832 (first edn, I9II: repr. Guernsey, I987), chs I I and I 2; E.J. Hobsbawm, Labouring Men (London, I964), esp. ch. 2; G. Rudé, The Crowd in History, I730-I848 (London, 1964); E.P. Thompson, The Making of the English Working Class (London, I963), chs 7 and I4.

5. In fact, by establishing (and fiercely guarding) the precedent that by far the most important context for action in eighteenth-century food riots was the statutory context of laws against forestalling and regrating, it could be argued that Thompson's work was the most influential factor in the propagation and persistence of this kind of approach. See E.P. Thompson, "The Moral Economy of the English Crowd in the Eighteenth Century", Past and Present, 50 (1971), pp. 76-136; idem, Customs in Common (London, 199I), ch. 5: "The Moral Economy Reviewed". 
The tenacity of this model is well illustrated in the recent appearance of Adrian Randall's exemplary volume, Riotous Assemblies. ${ }^{6}$ In it, he provides a comprehensive survey of popular protest in Hanoverian England with chapters on food riots, proto-industrial protests, agrarian disturbances, and the work of political mobs. He engages directly with the issue of the moral economy and its decline at the end of the century, and presents a thorough exploration of the wider political and social background to eighteenth-century disturbances. ${ }^{7}$ What he does not do (and, in fairness, does not set out to do) is to give us the immediate context of such disturbances. This is crucial, as the one thing that is demonstrably true of most Hanoverian popular disturbances - or at the very least, those outside the major cities - is that they were essentially local affairs. ${ }^{8}$

Despite the fact that they shared many common features, and that they often took place during moments of widespread disturbance (one thinks, for example, of the concentrated outbreaks of food riots across southern England in $1727-1729,1739-1740,1756-1757,1766-1768,1772-1773$, I795-I796, and particularly $\mathrm{I} 799-\mathrm{I} 80 \mathrm{I}^{9}$ ) historians generally agree that most individual acts of protest were confined to the locality (the parish, township or, at most, sub-region) where they took place, and that this confinement was both a symptom and a reflection of the local conditions which gave rise to a particular "protest event". Bob Bushaway, in particular, has demonstrated the way in which local customary protocols including doleing, perambulation, and other calendrical customs - clearly gave colour and a specific local context to "moments" of protest long into the nineteenth century. ${ }^{1 \circ}$ Curious, then, that we should have inherited a explanatory model of popular protest that largely ignores the particular local conditions that gave rise to them. Or perhaps not.

At the heart of this model, I would suggest, is an almost irresistible impulse to view "moments" of popular protest as existing within "movements" of the labouring poor. Mostly, this impulse is implicit. Even in Edward Thompson's groundbreaking work, by placing the customary protocols and precedents followed by protesting crowds at centre stage he

\section{A.J. Randall, Riotous Assemblies: Popular Protest in Hanoverian England (Oxford 2006). \\ 7. Ibid., chs I, 2, and 3 .}

8. It goes without saying that historians have treated popular disturbances in cities as qualitatively different to those in towns and in the countryside, emphasising that "[m]ore often [than not] [...] London riots were attached to a political cause". Nonetheless, it is also generally acknowledged that "beneath the surface" of even the most explicitly hostile "Church and King" disturbance, "there were common elements - no less in the methods than in the motives and 'generalized beliefs' of its participants [which] [...] even more than the issues themselves, [gave] it its peculiar and distinct identity"; Rudé, Crowd in History, pp. 51, 63-64.

9. Randall, Riotous Assemblies, p. 96.

Iо. R. Bushaway, By Rite: Custom, Ceremony and Community in England, 1700-1880 (London, 1982), esp. ch. 5. 
did so by and large to emphasize the similarity of protests across time and space. Moreover, he was adamant that the central structural factor in the development of food riots and contests over the moral economy in the eighteenth century was the abrogation of national, legislative protections against forestalling and regrating. ${ }^{\mathrm{II}}$ Local conditions may have given a protest its particular piquancy, but for Thompson it was the knowledge of, and a desire to reinforce, statutory marketplace protections that gave it its motive force.

Sometimes, the impulse to find "movements" of labourers is explicit. Returning to the events of r830, Hobsbawm and Rudé speak of the "improvised, archaic, spontaneous movements of resistance to the full triumph of rural capitalism", while Roger Wells refers directly to "the Swing movement of I830". ${ }^{2}$ Ian Dyck, too, speaks of Swing as a "movement", and of William Cobbett's role in articulating and co-ordinating "Swing's programme". ${ }^{3}$ Andrew Charlesworth, on the other hand, suggests that the lenient sentences meted out by Lord Knatchbull in Kent at the beginning of the disturbances was "[o]ne of the turning points in the movement"; and as a final example (and by way of contradistinction) John Merrimen suggests that, despite experiencing a Bourbon revolution and widespread popular protest countrywide, "the equivalent of a Captain Swing 'movement' did not exist in France in I830". ${ }^{4}$ That the disturbances in the English countryside in I 830 represent a "movement" of agricultural labourers is a given for just about every historian who has treated them seriously over the last forty years. Yet not one of them has felt the need to define precisely what they mean by the term. Usually, it is merely sufficient to point to the concentration of incidents and the similarities between them in order to establish the case.

Swing began in Kent in November I 830 and swiftly spread across the counties of southern England. It was largely the response of a proletarianized agricultural workforce to inadequate wages (which, since the I 790 s, had been routinely supplemented from the poor rates) and structural un- and under-employment. ${ }^{15}$ It was marked by attacks of arson against

ir. Thompson, "The Moral Economy of the English Crowd", pp. 83-88.

I 2. Hobsbawm and Rudé, Captain Swing, p. I9; R. Wells, "Tolpuddle in the Context of English Agrarian Labour History, I780-1850", in J. Rule (ed.), British Trade Unionism 1750-1850 (London, I988), p. I $2 \mathrm{I}$.

I3. I.C. Dyke, William Cobbett and Rural Popular Culture (Cambridge, I992), p. I89.

I4. M. Reed and R. Wells (eds) Class, Conflict and Protest in the English Countryside, I700-I 880 (London, I990), p. 58; J.M. Merrimen, "The Norman Fires of I 830 : Incendiaries and Fear in Rural France”, French Historical Studies, 9 (1976), pp. 463-464.

I 5 . For a much more detailed and nuanced account of the causes of the disturbances, see P.D. Jones, "Swing, Speenhamland and Rural Social Relations: The 'Moral Economy' of the English Crowd in the Nineteenth Century", Rural History, 32 (2007), pp. 272-29I, and C. Griffin, " "There Was No Law to Punish That Offence". 
farmers and others, by the breaking of threshing machines, the sending of anonymous letters, demands for higher wages and relief, and the exaction of customary "doles". Such actions were predominantly, though by no means exclusively, perpetrated by agricultural labourers, and most incidents during Swing shared many, if not most, of the above characteristics. All of this is true, and is highly compelling. But it is not, in itself, sufficient evidence that Swing constituted a "movement" in the sense implied by the Shorter Oxford English Dictionary: "A series of actions and endeavours by a body of persons tending more or less continuously towards some special end". ${ }^{16}$ There was, as most historians would no doubt agree, no "special end" towards which those who took part in the disturbances in I 830 were focused. Instead, there were a multitude of ends, many of them shared across place and time, some of them exceptional, and a few apparently contradictory; and in almost every case they were entirely related to the conditions and relationships that existed in the localities in which they were formulated and fought for. ${ }^{17}$ In other words, by this definition, Chartism was a movement, but the agrarian disturbances of 1830 were not.

Yet there is also something of a paradox in the way that precisely those historians who would claim a "movement" for Swing (either implicitly or explicitly) also decry its lack of focus, coordination, and that self same "special end" that would make it so. Hobsbawm and Rudé describe protesters as "improvised, archaic [and] spontaneous", Edward Thompson calls them "curiously indecisive and unbloodthirsty", and Roger Wells concludes that "they conformed to the precedents set thirty to forty years previously", and that "it was the intensity and the scale which made the Swing revolt [exceptional] [...] not the nature of the protest". Perhaps David Kent sums up their position most succinctly when he writes that "there was nothing mysterious about the causes of the Swing disturbances $[\ldots][t]$ hey stemmed from the grinding poverty which faced most agricultural workers in southern England". ${ }^{8}$ First, Swing is identified as a "movement" of agricultural labourers (and others) on no other evidence than a concentration of events in space and time, and then those who

\section{I6. My emphasis.}

17. A simple illustration of this can be found in Appendix 3 of Hobsbawm and Rude, Captain Swing, p. 3II, where (for the purposes of accounting) they break down the disturbances into seventeen separate categories, from arson, "riots", robbery and agricultural machine breaking, to rent riots, sedition, poorhouse riots, and strikes. In terms of each individual incident, these categories themselves could be subdivided endlessly.

18. Hobsbawm and Rudé, Captain Swing, p. I2; R. Wells, "The Development of the English Rural Proletariat and Social Protest, I700-I 850", in Reed and Wells, Class, Conflict and Protest in the English Countryside, p. 30; Thompson, The Making of the English Working Class, p. 250; D. Kent, Popular Radicalism and the Swing Riots in Central Hampshire (Hampshire Papers Series: Winchester, I997), p. I. 
constituted the movement's "foot soldiers" are accused of exhibiting an archaic, indecisive, reactionary (false) consciousness for not following the "single end" of - what precisely? On this subject, Swing's historians are mute. This seems to be a case of having one's Fabian cake and eating it. The closest we get to an explanation of what is missing from Swing's "movement" is the vague fingering of a lack of "class consciousness", but this remains very much a hidden agenda on the part of most historians.

What follows, then, is an attempt to make sense of Swing according to a different paradigm. The next section investigates how and why the discrete events that made up the disturbances have appeared so compellingly as a "movement", not only to historians, but to contemporaries in pre-Reform England. The discussion then moves on to present a detailed study of a particular "moment" of protest (in Berkshire, at the end of November I 830) that dispenses with any notion of a "movement" of agricultural labourers across southern England, and instead depends entirely on a detailed understanding of the specific local conditions that underpinned it. In taking this detailed (one might even say "micro-historical") approach to a specific incident within the overall frame of reference of the disturbances countrywide, it is possible to present an alternative model of popular protest which acknowledges the overwhelming influence of economic and social relations in the locality without ignoring the "bigger picture".

As such, this essay will conclude with the suggestion that periods of closely related disturbances, such as Swing, might best be conceptualized as "meta-movements", meaning that they were composed of a series of interrelated incidents and events that occurred across a broad canvas (in this case, nationwide), yet which were individually defined by an intense localism and an active rejection of anything resembling a guiding principle or unifying set of demands.

\section{“CAPTAIN SWING” THE SIGNATORY}

The question of who or what "Captain Swing" actually was in relation to the events of 1830 is central, yet it is one that has seems to have escaped the attention of just about everyone who has looked at them. Most historians follow Hobsbawm and Rudé's formidable lead in using "Swing" as a metonym, a substitute identity not only for the perpetrators, but for the discrete events that took place during the period of the disturbances. ${ }^{19}$ But, as we shall see, in I 830 and I 83 I the character of "Swing" took on a number of narrative identities whose paths crossed and re-crossed in the public imagination, and an understanding of the way in which the identity of Swing appeared and then evolved in a number of different contexts is of

19. Hobsbawm and Rudé, Captain Swing, chs II and I2. 
crucial importance in explaining how contemporaries and subsequent commentators have given meaning to the disturbances.

According to Carl Griffin, who recently reassessed the origins of the disturbances in Kent, the eponymous "Swing" first put his name to a threatening letter in Dover in early October I830: "You are advised", he wrote to a farmer, "that if you doant put away your thrashing machine against Monday next you shall have a 'SWING'. ${ }^{\circ}$ Thereafter, his name was chalked on walls between Dover and Canterbury, and scores of letters signed in his name were received by victims of arson and machine-breaking over the following months and, indeed, years. The creation of an eponym during periods of popular protest is not confined to the labourers' revolt of I 830, of course: it is easily recognisable during the Luddite disturbances of I 8 I I-I 817 and the Rebecca Riots in Wales during the I840s, for example. ${ }^{21}$ Indeed it is possible to see something similar happening during many periods of popular protest in the eighteenth and early nineteenth centuries. Adrian Randall and others have pointed to the figure of Jack O'Lent, who was synonymous with the riots against the Bristol turnpikes in 1749 , to show how the development of an eponymous figurehead is at least partially explicable within the framework of the carnivalesque milieu of popular culture, custom and practice that formed the backdrop to rural protest. ${ }^{22}$

Alun Howkins and Linda Merrick go even further in their 1993 study of "Ritual, Disguise and Rebellion", providing a sophisticated anthropological rationale to demonstrate that the practices of disguise, cross-dressing and face-blacking were essential components of protest throughout Hanoverian England and Wales - all ways of creating alternative identities that share characteristics with eponymous invention. ${ }^{23}$ They point to the transformative function of such disguise, allowing participants to transgress not only the rigid normative rules of the tightly stratified society within which they lived, but the internal rules of their own communities, cultures, and even households. They suggest that it is only through the agency of disguise - of which the use of an eponymous "other" is also a clear example - that individuals could act as they must in extremis while safeguarding the very rules that they have chosen (or been forced) to transgress.

20. C. Griffin, "Affecting Violence: Language, Gesture \& Performance in Early Nineteenth Century English Popular Protest”, Historical Geography, 36 (2008, forthcoming).

21. See, for example, K. Binfield, The Writings of the Luddites (Baltimore, MD, 2004), esp. Introduction; D. Williams, The Rebecca Riots: A Study In Agrarian Discontent (Cardiff, I955). 22. A. Charlesworth, R. Sheldon, A.J. Randall and D. Walsh, "The Jack-a-Lent Riots and Opposition to Turnpikes in the Bristol Region in I749", in A.J. Randall and A. Charlesworth (eds), Markets, Market Culture and Popular Protest in Eighteenth-Century Britain and Ireland (Liverpool, 1996), pp. 46-68.

23. A. Howkins and L. Merrick, "Wee Be Black as Hell': Ritual, Disguise and Rebellion", Rural History, 4 (1993), pp. 4I-53. 
But as useful as this perspective is in assessing the mentalite of protesting crowds (to use Edward Thompson's favoured term), it turns out to be much less profitable within the context of the "last labourers' revolt". Although isolated examples can be found of individuals disguising themselves in 1830 and I $83 \mathrm{I}$, one of the defining characteristics of the protesting crowds was their transparency and a lack of ambiguity. ${ }^{24}$ Crowds broke machines, petitioned for higher wages, and even committed robbery (in statutory terms) in the full light of day, largely without any thought of disguise, and often over protracted periods lasting two or three days. Clearly, most of those involved had little intention of evading capture, and no sense of conflict in terms of the "norms" and "rules" they transgressed in doing so.

Alternatively, Kevin Binfield provides a linguistic rationale for the development of the mythic figurehead with specific reference to Luddism. In fact, he suggests that Ned Ludd was both "an eponym for a subculture, a selective trade culture, that grew out of a larger culture", and "a metonym that [protesters] hoped could concentrate a variety of discourses and enable [them] [...] to constitute themselves as a self-determining and articulate body". ${ }^{25}$ In other words, Binfield suggests that the creation of Ned Ludd was not so much a case of inventing a disguise for the purposes of anonymity or license as a means by which coherence could be conferred to a disparate set of discourses which constituted protests across time and space. Once again, though, in the case of Swing this perspective is less than convincing. Despite the fact that "Swing" appended his name to a number of threatening letters during the disturbances, many others were received by farmers on which he made no appearance at all. ${ }^{26}$ Far more importantly, there is little or no evidence in the sources that Swing was a figurehead recognized as such by those who actually took part in the disturbances, either as arsonists or protesters, and as such he cannot be said to act as a point of coalescence for a "movement" of agricultural labourers as Binfield suggests is the case with Ned Ludd. No mention that I am aware of was made of him directly during crowd actions, and the number of incidents that were accompanied by threatening letters, let alone those signed by Swing, is negligible. ${ }^{27}$

\footnotetext{
24. Griffin, “There Was No Law to Punish that Offence”, p. I 53.

25. Binfield, Writings of the Luddites, pp. 22, $3 \mathrm{I}$.

26. For example, of the twenty-eight threatening letters sent during the period of the disturbances which are collected in the Home Office papers $\left(\mathrm{HO}_{52}\right)$ at the National Archives, fifteen are either signed by "Swing" or make direct reference to him, and thirteen make none at all.

27. For example, in Appendix 3 Hobsbawm and Rudé list the number and type of disturbance they collected by location: of the 3 I 6 locations where arson attacks took place, only i 8 also register the receipt of threatening letters, and of the $\mathrm{I}, 060$ locations where other, overt incidents occurred, only io also registered threatening letters; Hobsbawm and Rudé, Captain Swing, pp. 3 I I -358 .
} 
Of course, the very question of who authored threatening letters, and what their motivation might be, is highly vexed and has troubled a number of historians. Even the briefest survey of Swing letters is enough to convince us that a multiplicity of voices is represented: to quote Edward Thompson again, "one can rarely prove that any letter indicates general protest rather than the voice of a crank". ${ }^{28}$ Sometimes, it is easy to tie a specific threat to other evidence in order to indicate that the author or authors were local and were, at the very least, acting on behalf of aggrieved labourers. A letter received by Dr Jones of Bedfont informed him that "[i]f you do not do a something for the numerous poor of this Parish [...] we mean to serve you as we did our neighbour", alluding directly to a fire in the town that occurred two weeks earlier. ${ }^{29}$ But ultimately, we are forced back on Thompson's uncharacteristically vague conclusion that "one is left to judge by the 'feel' of a letter, its style [and] the particularization of grievances" ${ }^{30}$; and in the case of the so-called "Swing" letters, one is also forced to the conclusion that many (perhaps even the majority) had little or no connection with agricultural labourers themselves.

Take, for example, the rhetorical flourishes of which "Swing" writers were so fond. "You have gorged upon the vitals of the poor half starved labourer till he has sworn to wear the chains of slavery no longer", wrote Swing to a farmer in Horsham: "Not a Barn Outhouse Stack or even your own Dwelling House shall escape the devouring element". "Your name is down amongst the Black Hearts in the Black Book and this is to advise you and the like of you, who are Parson Justices, to make your Wills", he wrote again, this time to Farmer Biddle of High Wycombe. A note dropped on the outskirts of Coventry contained the simple but potent message: "The Bag is Burst wee shall soon be with you between now and Christmas". ${ }^{\text {I }}$

What also becomes clear is that very quickly, following his emergence in Kent in October I830, Swing the signatory assumed a number of guises, signing letters that aired a multiplicity of grievances. A letter received by W.M. Hurlock in Dedham, Essex, for example seems to have been written by a local farmer or farmers who resented his position as Lecturer of the Parish and receiver of the Great Tithes: "Prepare your wicked soul for Death", it warns, "[ $t]$ here is not a Farmer in the parish but what hates you". ${ }^{32}$ The picture becomes even less clear when Swing

28. Thompson, “The Crime of Anonymity”, in D. Hay, P. Linebaugh, J. Rule, E.P. Thompson, and C. Winslow, Albion's Fatal Tree (repr. London, 1988), pp. 273-274.

29. The National Archives [hereafter TNA] HO52/8/634 (Home Office Correspondence Relating to Disturbances in Specific Counties), fo. I64.

30. Thompson, "Crime of Anonymity", p. 274.

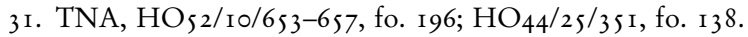

32. TNA, $\mathrm{HO}_{52 / 7 / 403}$, fo. I 53 . 
signed letters with an overtly macro-political message, such as the one received at Coventry which called for "[an end to] machinery and a free trade in corn", or another that demanded "Parliamentary Reform in a full and fair representation of the people or Death!!!". ${ }^{33}$ Still more, how are we to assess the "authenticity" (in this context) of a letter dropped in Kent which purported to have been written at the "Hotel de France", and began, "My spelling is bad but de French are not so English", especially as the author clearly had a grievance against a particular local landowner. "Monsieur", he wrote in his best Franglais, "de English be upon it, if we do not come, de moon does not shine nor does stars look bright to night [...]. The lane down to your farm is dark - we will light it up". ${ }^{34}$

\section{THE MYTH OF “SWING” AND THE PUBLIC MIND}

Questions of "authenticity" hover over these letters like flies over a corpse, and it is a brave historian indeed who would attempt to pick the bones for anything resembling empirical truth. But if we shift our focus away from normative questions of social history then perhaps we can begin to see a different kind of truth emerging in the pattern and progress of Swing's output. That Swing emerged as an eponymous figure in Kent in October I830, a mythic figure who could speak anonymously for the grievances of labourers, is not in doubt (regardless of who wrote his letters for him). That he was taken up by others who were definitely not labourers, and who had their own specific or more general axes to grind is also self-evident. Yet the truth that there appear to be a number of discrete Swings behind the letters should not blind us to the fact that they were, in one crucial sense, mutually dependent: the case of each of these different constituencies could only have been strengthened by the continuing progress of the myth of Captain Swing.

Word of the letters circulated quickly in the locality, adding to an already heightened atmosphere of tension and fear; mention of them found their way into the local press and thereafter into the national papers. This, of course, stimulated every disaffected employee, every sympathetic radical, and a sprinkling of cranks and crackpots to have a go themselves. Edward Thompson has suggested that by the earliest years of the nineteenth century, Home Secretary Portland was cautioning against reprinting anonymous threatening letters for fear of adding to the notoriety of the authors and inviting imitation, and despite the unprecedented upsurge in the numbers of such letters during 1830 and I $83 \mathrm{I}$, it is nonetheless true that the text of very few actually appeared in the press. ${ }^{35}$ Yet something had happened which

35. Thompson, “The Crime of Anonymity", pp. 26I-263. 
served to advertise them far better even than the reprinting of their contents: that something was the signature of Swing.

As early as the beginning of December i 830, it was sufficient for the Hampshire Chronicle merely to report that "[n]umbers of 'Swing' letters continue to be received by farmers on the Isle of Thanet" for their readers to understand precisely the nature of the threat. ${ }^{36}$ The press rarely found it necessary to debate the authorship or "authenticity" of a Swing letter, either; indeed, as we have seen, many of those alluded to were not even signed by Swing himself. But having begun as the author of threatening letters, by mid-December Swing was beginning to take on a much more tangible form. On I 8 December, The Times (after the Leeds Intelligencer) reported that "Captain 'Swing' has got into Yorkshire", in response to fires and the destruction of machinery in the south of the county. ${ }^{37} \mathrm{On} 2 \mathrm{I}$ December, the Taunton Courier printed a letter addressed directly to Swing, arguing against his methods and describing him as "a stout fellow, but a bad adviser". ${ }^{38}$ The culmination of this personification of Swing occurred around 23 December, when the Morning Chronicle (among others) sensationally announced the "arrest of Captain Swing" in Suffolk.

Swing, it reported, was none other than Joseph Saville, a former corn factor who was latterly "more in the straw plait line". He was apprehended and taken before the magistrates at Bury after being spotted throwing inflammatory letters bearing the signature "Swing" from a gig. ${ }^{39}$ The Times reported that his arrest caused "a more than ordinary sensation", and it was rumoured that he was "the actual and original Swing”, an impression strengthened by the apparent discovery of another 600 or 700 letters and more than $£ 500$ in cash on his person. In the end, the authorities decided that Saville was a relatively harmless crackpot, and his sentence of a $£ 50$ fine and I 2 months imprisonment stands in stark contrast to that of others who were convicted of sending only a single threatening letter, yet were sentenced to 7 years' transportation. ${ }^{40}$

The point here is not whether Saville actually was the "real Captain Swing", nor even whether the press believed him to be so. Rather, it is how and why a situation had arisen whereby a man not directly connected with the plight of agricultural labourers, a man very much on the fringes of rural society, could generate so much interest by appearing to be the real Captain Swing. The answer, of course, is that his case fed directly into the imagination of the wider reading public that was, by 1830 , just about ready to believe almost any tale of conspiracy and intrigue. And in 
turn, this explains another important theme in the rhetorical construction of Swing that emerged soon after the disturbances began: the claim that outsiders, agents and provocateurs were to blame for fomenting them, rather than the feelings and experiences of ordinary agricultural labourers. Correspondents to Colonel Jervoise of the North Hants Militia wrote to him of their fears that "the people are discontented by agency for concealed purposes", and that "there is some secret engine at work that has not yet been discovered". ${ }^{41}$ As late as 1832 , one Devon clergyman concluded that " $[t]$ he commencement of the fires, I always fancied, [was] aided by emissaries from France or Ireland". ${ }^{2}$

In the heady atmosphere of pre-Reform England, with revolution in continental Europe close at hand, such conspiracies are hardly surprising. But it is important to note, once again, that the press did little to diminish them. Newspapers printed account after account of "strangers" who incited, and even ignited, the fires that lit up southern England. According to them, the mysterious Swing was a malcontent, possibly foreign, certainly politically motivated, and always "respectable" in manners or dress. The Times gave details of "a man, dressed in shabby genteel, but of manners apparently above the ordinary class", who had been spotted close to fires at Battle, Sussex. The Examiner reported that "previous to several of the [...] fires in Kent [...] a post chaise had arrived in the neighbourhood, and after staying a short time, had gone away again". ${ }^{43}$ This cloak-and-dagger Swing, a man of "gentlemanly appearance", 44 whose motives were concealed but who sought to bring instability and discontent to the countryside, clearly fed on, and in turn sustained, the enigmatic letter-writing Swing. In the heightened atmosphere of November and December i 830 , it was virtually impossible for onlookers to separate the two.

What is of most interest here is the way in which the mysterious and enigmatic figure of Swing - first as a writer of threatening letters and then as a shadowy, well-dressed malcontent - moved from the farmyards and lanes of rural England, through the imaginations of newspaper correspondents and leader writers, and back into the countryside again. At one stage, at the beginning of December, even The Times (hardly innocent in sustaining the mythology of Swing) was moved to report that in Hampshire: "A traveller in this unfrequented part who is too inquisitive

4I. Hampshire Record Office [hereafter HRO] 44 M69/96/2/I/38, J. Fitzgerald to G.P. Jervoise, 27 November I 830; J. Croft to G.P. Jervoise, 8 December 1830.

42. Report from His Majesty's Commissioners for Inquiring into the Administration and Practical Operation of the Poor Laws I834, Appendix B(I), "Answers to Rural Queries in Five Parts"; Part 5, pp. 23, I25.

43. The Times, I9 November I830; The Examiner, November 1830 .

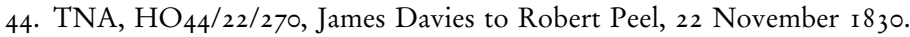




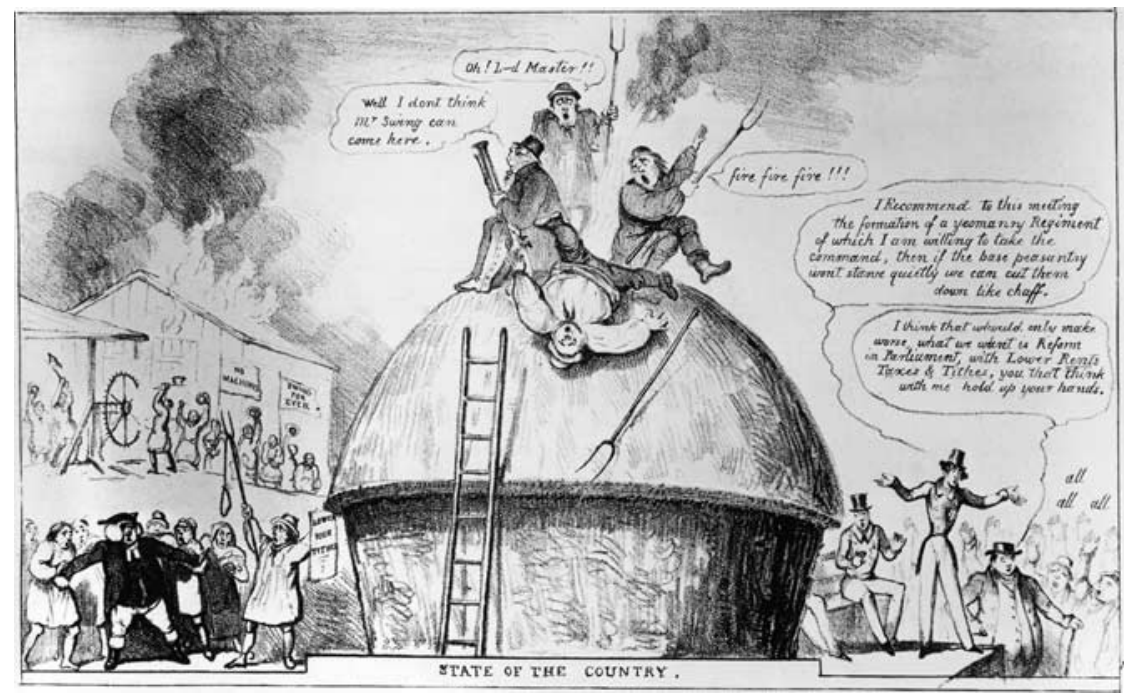

Figure I. A contemporary cartoon that neatly shows not only the personification of "Captain Swing" in the public mind, but also the way that the disturbances as a whole became coopted by many factions in pre-Reform England.

Time E Life Pictures/Getty Images. Used with permission.

is sure to excite suspicion [...]. Gentlemen in gigs and postchaises are peculiar objects of jealousy [...] [and] an innocent inquiry of, 'Whose house or farm is that?' is, under existing circumstances, an overt act of incendiarism." ${ }^{45}$ Though it is a difficult commodity to measure, there can be little doubt that the growing mythology of Swing served both to advertise, and to strengthen and invigorate the disturbances as they spread from the eastern counties across the whole of southern England. Word of his progress reached as far west as Taunton in Somerset, where his emissaries sent a letter to a woollen manufacturer at Shepton Mallet suggesting that "[a]s Swing is travelling on his [way] through England, he must nesessily [sic] soon be here". ${ }^{6}$

This symbiotic relationship between events on the ground and the widespread reporting of them raises important questions about the proprietorship of an eponymous figurehead. Kevin Binfield suggests that "Luddism [as a movement] is generated not by conspiracy or the sudden emergence of class consciousness, but by a single, forceful act of naming - the creation and appropriation of the eponym 'Ned Ludd"” ${ }^{47}$ During the so-called "Swing

47. Binfield, Writings of the Luddites, p. I I. 
risings", though, things are much more complicated. There is little doubt that the creation of the mythic Swing contributed to the momentum in the countryside; we might even suggest that he was absolutely vital, as a figure around which events could cohere in the public mind. But this is very different from suggesting that the creation of the eponym "Swing" created a coherent "movement" of these discrete events, or even that such a "movement" was self-naming in the way that Binfield claims for Luddism. The "naming" of Swing - indeed, his mythic creation - was less a conscious act on the part of agricultural labourers than the result of a symbiotic relationship between labourers, cranks, crackpots, Radicals, leader writers, frightened farmers, correspondents, and finally the imagination of a public hard-wired in I 830 to find Frenchmen, Free Irishmen, and radical agitators hiding behind every haystack and lurking down every country lane.

Perhaps the most useful way of understanding the role of Captain Swing is to follow the lead of Katrina Navickas, another biographer of Ned Ludd. In her recent Social History article on "The Mythology of Luddism" she goes beyond Binfield's definition of it as an act of selfnaming, suggesting rather that "'General Ludd' was perhaps only the most visible manifestation of what was in fact a mythology of Luddism, a whole mindframe of opposition which was framed by both participants in, and suppressors of, the disturbances". ${ }^{48}$ In a similar way, Swing too was formed by the psychological needs of protesters and opponents of the disturbances, and in this case the balance of influence probably tipped in favour of those who required an enemy on which to focus their fears and disapproval rather than protesters who sought a mythical ally. In the drawing rooms of Kensington and the farmhouses of Kent, Swing was an agent provocateur, possibly French or Irish, but more likely one of the home-grown variety.

Little wonder, then, that two of pre-Reform England's most notorious agitators - Cobbett and Carlisle - were prosecuted for sedition and incitement in the months immediately following the disturbances. But Cobbett (who was many contemporaries' best bet for the "real" Captain Swing) knew better. On the influence of "outsiders" and "designing Radicals" in the disturbances, he wrote:

Men that talk much are apt to do very little; and I, if I had ricks and barns at stake, I should be more afraid of the vengeful feelings of one single labourer, whose son or brother I had caused to be imprisoned or severely dealt with for poaching, than I should be of all the speeches, the writings, and the machinations of all the discontented spirits in London who, besides all the rest, hardly know wheat from peas when they see them, hardly know a rick from a barn; and certainly do not know a barn from a stable; are totally ignorant of the state of

48. K. Navickas, "The Search for General Ludd: The Mythology of Luddism”, Social History, $30(2005)$, p. 284 . 
homesteads and the means of assailing them; [and] would be frightened out of their wits at the idea of going along a dark lane or over a down by themselves. ${ }^{49}$

Clearly, contemporaries felt compelled to find some "organizing principle" behind the disturbances of 1830 , and in the absence of any real evidence they allowed their imagination and the rhetorical tool of the press to do the job for them.

What is more surprising, though, is the extent to which historians have gone along with this exercise. Not only have most used the language of a "movement" when describing the disturbances, as I have already suggested, but one or two have even attempted to find radical conspiracies of their own. The most notable exercise of this kind is Roger Wells's I997 article, "Mr William Cobbett, Captain Swing, and King William IV", in which he ties together the loose ends of Cobbett's lecture tour of the southern counties, the appearance in east Sussex of Treasury Solicitor, George Maule, the slightly unhinged figure of former London policeman Charles Inskipp, and the close interest of the King into a common thread of political influence in the events around Battle in East Sussex. ${ }^{\circ}$ In the final analysis, though, the ends remain loose and, while it would be foolhardy to deny any involvement of known radicals in the events of I 830, the evidence simply does not exist to suggest that they played anything other than a minor supporting role. It is impossible to imagine that the "village Hamdens" of pre-Reform England could be persuaded to stay out of the events as they unfolded, but this is very different from suggesting that they were instrumental in any substantial way. ${ }^{\text {I }}$

\section{LOCATING POPULAR PROTEST IN ITS LOCAL CONTEXT}

When one looks in detail at individual "moments" of protest, one is forced to the conclusion that Cobbett had it just about right; that these were quintessentially local events, explicable only with direct reference to the local conditions from which they arose. Take, for example, the crowd actions that took place around Hungerford and Kintbury on 2I and 22 November I830. These two settlements lie on the banks of the River Kennet in Berkshire (see Figures 2 and 3). In 1830 , Hungerford was a prosperous market town of 2,700 souls dominated by agriculture and the artisan trades. Kintbury was smaller, having a population of around I,700, and its dependence on agriculture was even greater.

49. William Cobbett, Two-Penny Trash, V.i (8), February i 83 I.

50. R. Wells, "William Cobbett, Captain Swing, and King William IV", Agricultural History Review, 45 (1997), pp. 34-48. For another, localized attempt to "politicize" Captain Swing, see also Kent, Popular Radicalism.

5. See esp. ibid., pp. 5-19. 


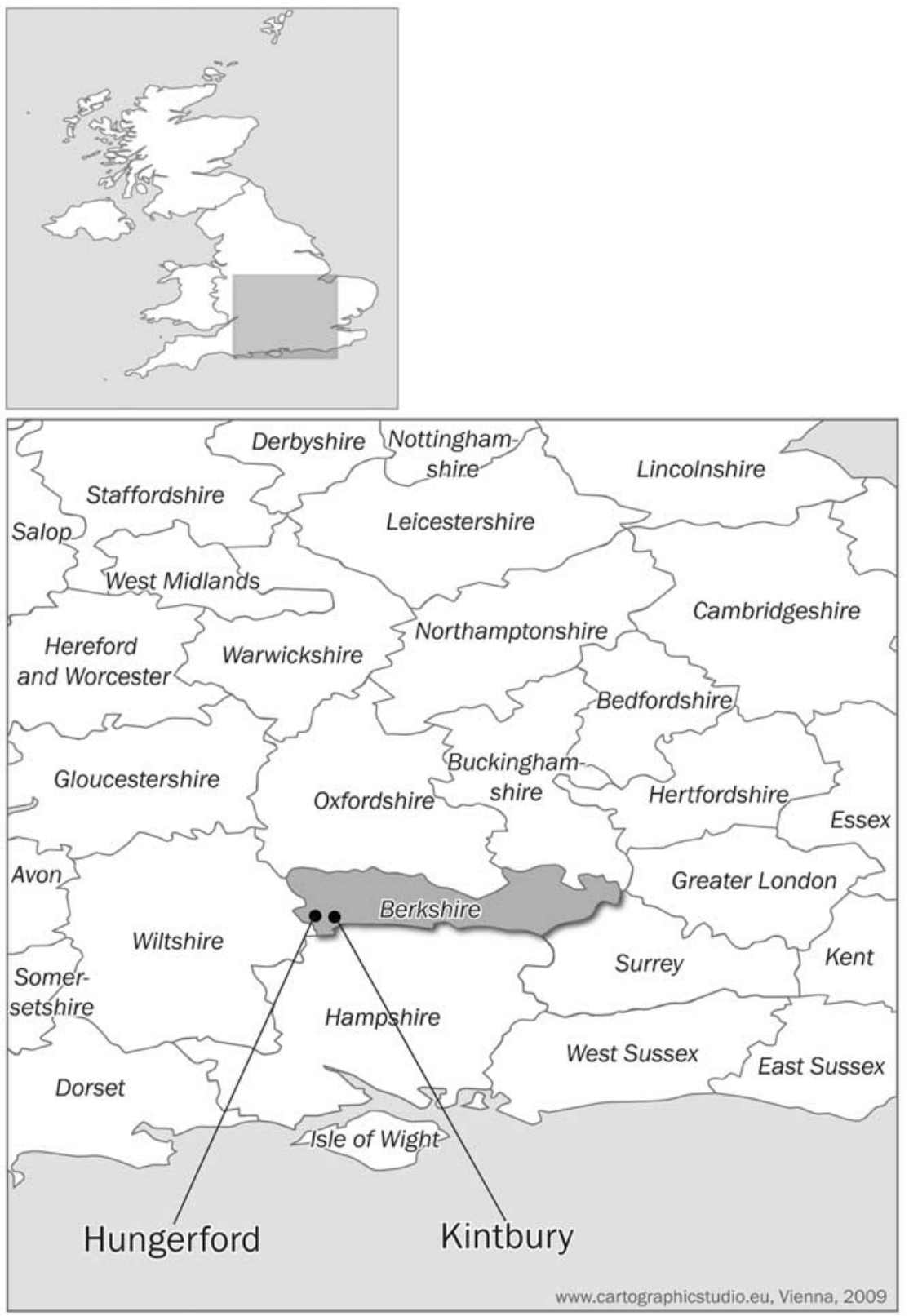

Figure 2. County map of England and Wales, showing the location of Hungerford and Kintbury, Berkshire. 


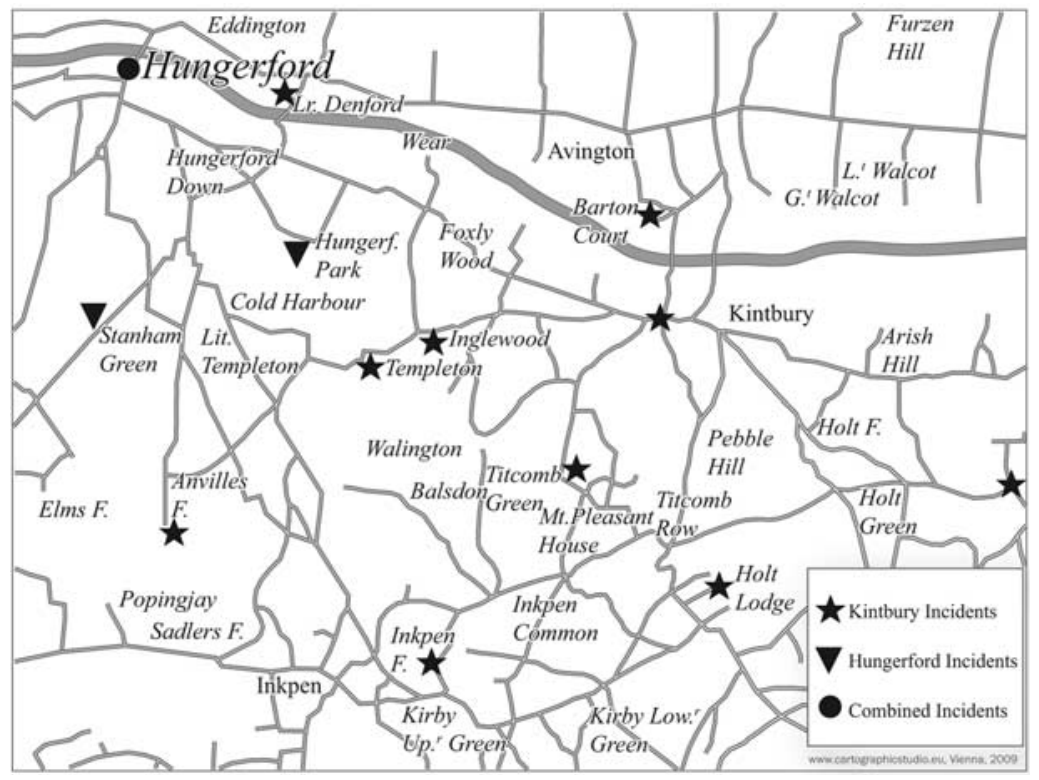

Figure 3. Sites of crowd action at Kintbury and Hungerford, 2 I-22 November 1830.

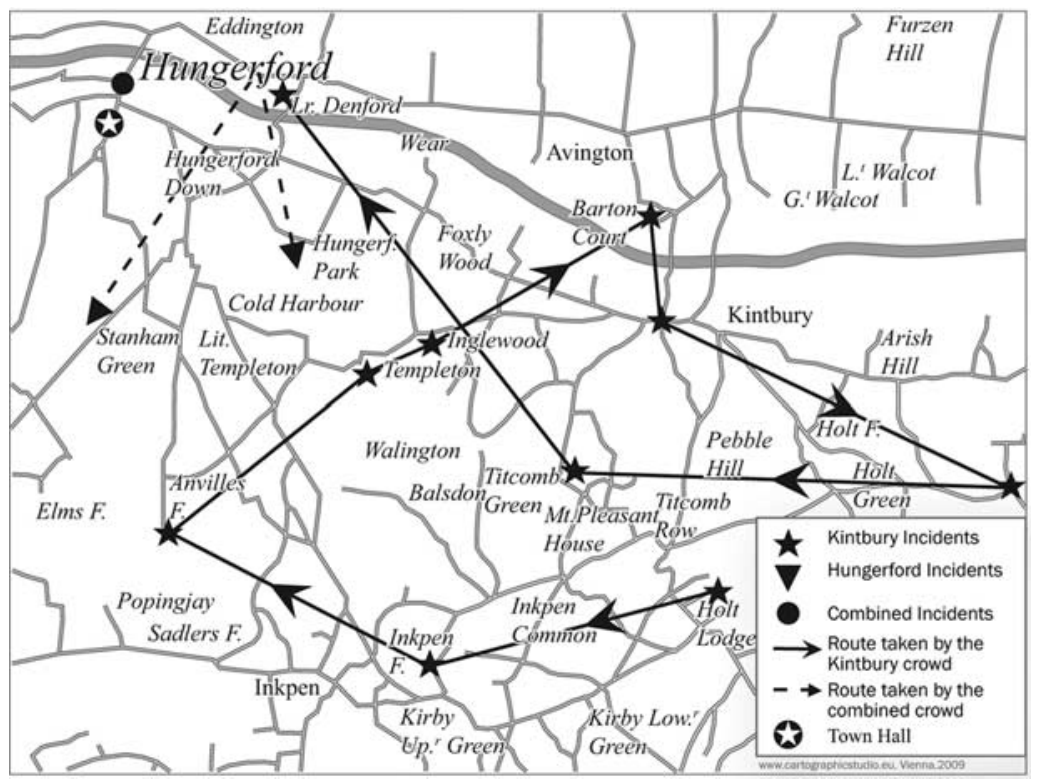

Figure 4. The paths taken by the Kintbury and Hungerford crowds during the disturbances 2 I-22 November I 830. 
On 2 I November I 830 a vagrant approached the house of Mr Hogan Smith of Kintbury Holt, overseer, and asked for relief, but instead he was thrown into the Blind House, or Cage (the local lock-up). On hearing this, local labourers proceeded to liberate him not once but twice. ${ }^{52}$ Later that evening, a crowd of around 200 arrived at a farm at Inkpen and broke a threshing machine there, and then went on to another farm at Anvilles and did the same thing. ${ }^{53}$ In the early hours of the following morning, the crowd processioned around Kintbury, breaking threshing machines and demanding money and victuals from farmers and others, including Captain Dunn of Inglewood House and the Revd Fowle, Vicar of Kintbury (see Figure 4$).^{54}$

They also persuaded Revd Fowle to act as intermediary for them, and had the threshing machines of Charles Dundas, MP brought into the centre of the town where they were destroyed, along with that of Thomas Leaver. 55 By 5 am the crowd had made its way to Hampstead Marshall where demands were made of Joseph Randall for food and cash. Having resisted them, Randall's window, sash, and frame were beaten in. ${ }^{56}$ By 8 o'clock, the crowd had made its way to Titcomb, where the machines of Frederick Webb were destroyed, and then on to Denford where they visited John Willes's estate at Hungerford Park and George Cherry of Denford House. ${ }^{57}$

Eventually, the Kintbury crowd met with around Ioo men from Hungerford who had been engaged in destroying threshing machines in Stanham Green and other places south of the town. On the main London Road (now the $\mathrm{A}_{4}$ ), the combined crowd was met by a party of local ratepayers and gentlemen who persuaded them to appoint a deputation and to meet with them later at Hungerford Town Hall. ${ }^{58}$ On their way into the town, the crowd broke windows and proceeded to destroy the ironwork and moulds at Richard Gibbons's foundry in the High Street. ${ }^{59}$ The men then went on to the Town Hall as appointed, where a deputation of five men from each location (Kintbury and Hungerford) negotiated on their behalf.

The Hungerford representatives successfully requested 2 shillings a day in wages for labourers until Lady Day next, and $2 \mathrm{~s}$ and $6 \mathrm{~d}$ a day thereafter,

52. TNA, $\mathrm{HO}_{52} / 6$, fo. 60 .

53. The Times, 3 January I 83 I, and Reading Mercury, 3 January I 83 I, cited in J. Chambers, The Berkshire Machine Breakers: The Story of the I830 Riots (Letchworth, 1999), p. 40; TNA, $\mathrm{HO}_{52} / 6$, fo. 47 .

54. TNA, TS I I/849 (Treasury Solicitor's Papers Relating to the Berkshire Special Commission), Bundle $\mathrm{I}$.

55. TNA, 52/6, fo. 45 .

56. TNA, TS I I $/ 849$, Bundle I.

57. TNA, $\mathrm{HO}_{52} / 6$, fos $47,5 \mathrm{I}$.

58. TNA, $\mathrm{HO}_{52} / 6$, fo. 47 .

59. TNA, $\mathrm{HO}_{52}$, fo. 16 . 
and then left the meeting. The Kintbury men were both more militant and more intransigent: they refused to leave their weapons outside, they demanded the same as the Hungerford men, and finally they demanded a one-off payment of $\mathfrak{E}_{5}$, threatening that "they would be Damned if they would not smash the Place, and down with the Town altogether" if they did not get it. ${ }^{60}$ The leader of the ratepayers' delegation, Mr. Willes, then gave them 5 sovereigns, and proceeded to offer the same amount to the Hungerford delegation gratuitously, believing it would be unfair to treat them differently as they had behaved "so well" during the negotiations. ${ }^{61}$ There was some indication later that the money had been given on the condition that it would spent in Hungerford itself. ${ }^{62}$

Following the Town Hall meeting there was much drunkenness and disturbance in Hungerford town centre, and the Bath to London coach was stopped and damaged, and money extorted from its passengers. Disorder and demands for money and food continued in the town that afternoon and into the evening. Most of the Kintbury men returned home following the meeting, but not before they had demanded $\mathfrak{E}_{5}$ and a promissory note for 20 s worth of beer from Farmer William Clarkson and a visitor, Herbert Hogsflesh. ${ }^{63}$

These are, of course, only the bare facts, but immediately we can make a number of observations on the progress of the disturbances. The first is that the Hungerford and Kintbury crowds comprised two quite distinct bodies of men. Both had been engaged in coercive behaviour around their own towns before coming together - serendipitously or otherwise - on the London Road. Looking particularly at Kintbury (for which the Home Office records are unusually rich) it becomes clear that a specifically circumscribed procession around the town was its primary activity (see Figure 4).

It is also important to note that even though the two crowds had already combined by the time the gentlemen met them on the London Road, during negotiations at Hungerford Town Hall it was obvious to both sides that delegates from the two localities should be dealt with separately, despite their core demands (of an increase in labourers' wages) being identical. In other words, the disturbances were highly and selfconsciously localized both in conception and progress, being demarcated along place or parish lines. The second observation is that despite the obvious risks attached to any open activity of this kind, the crowds in no way sought to mitigate their actions by avoiding those in a position

60. TNA, ASSI 6/I, Part 3 (Examinations and Depositions Relating to Riots in Berkshire, taken for the Reading Special Commission).

61. Berkshire Chronicle, I January i 83 I.

62. TNA, $\mathrm{HO}_{52} / 6$, fo. 27

63. TNA, ASSI 6/I, Part 3. 
of local authority. In fact, the Kintbury crowd seems to have gone out of its way to target the most influential parishioners: Charles Dundas of Barton Court was MP for Berkshire and later Lord Amesbury; George Cherry of Denford House was a JP and Under Sheriff of Berkshire, a post previously held by John Willes of Hungerford Park; the Revd Fulwar Craven Fowle, a relative of the Earl of Craven, was also a magistrate and was unusually well connected, having come to the attention not only of Jane Austen (who, it was rumoured, wrote verses for him) but of George III himself. Of the others, Captain (later Major-General) William Dunn of Inglewood House was a major landowner, and Mr Cuthbert Johnson of Wallingtons was lord of the manors of Wallington and Balsdon.

Thirdly, although most crowd activity related to wages and hindrances to the employment of agricultural labourers (threshing machines), they also appear quite specifically to have targeted the Richard Gibbons iron foundry, despite being told on arrival that no threshing machines were actually made there. Indeed, one of the leaders of the Hungerford crowd, John Aldridge, was heard to remark as he destroyed a threshing machine earlier in the day, that, "I would like to down with all the foundries". ${ }^{64}$ The Revd Fowle (among others) later observed that "Ploughs with cast iron shears appear to be as much the object of their hatred as machines, and I hear they have broken many." 65 This would suggest that it was not simply threshing machines that were problematic for the protesters, but the issue of the mechanization of tasks per se in an environment of rising un- and under-employment (though it may also have had something to do with the influence of blacksmiths in the crowd, who recognized the foundry and its products as a direct threat to their livelihood; John Aldridge was himself an apprentice blacksmith).

Finally, it is important to note that really disorderly behaviour seems only to have occurred as a result of the crowd meeting en masse in the centre of Hungerford. Prior to this, Frederick Page noted that "the conduct of the Labourers was almost without exception marked by forbearance and civility", and the Kintbury crowd in particular seems to have been marked by its self-discipline. ${ }^{66}$ In fact, there is a real sense that the ratepayers brought this disorder upon themselves: it was they who suggested the mass meeting (of up to $500 \mathrm{men}$ ) in the centre of town, and they who apparently made the condition that the money they

64. TNA, TS i i/85 i (Treasury Solicitor's Papers Relating to the Berkshire Special Commission: Depositions), unnumbered.

65. TNA, $\mathrm{HO}_{52} / 6$, fos 27,45 .

66. TNA, HO52/6, fo. I I. In fact, the leaders of the Kintbury crowd specifically admonished their members for ill-discipline, ordering some of their members to return rabbits they had stolen to their rightful owner, and even throwing one man in the canal for stealing an umbrella from a farmer they had visited; TNA, HO 52/6, fo. $5 \mathrm{I}$. 
Table I. Victims of the Kintbury crowd, 2 I-22 November I 830 , and their links with the parish vestry

\begin{tabular}{lll}
\hline Name of victim & \multicolumn{1}{c}{ Residence } & \multicolumn{1}{c}{ Links to the vestry } \\
\hline Alexander, William & Titcomb & Not known \\
Cherry, George & Denford House & Vestryman (unspecified) \\
Johnson, Cuthbert & Wallingtons & Vestryman (unspecified) \\
Dundas, Charles, MP & Barton Court & Vestryman, Visitor of the Poor \\
Dunn, Captain & Inglewood House & Vestryman (unspecified) \\
Fowle, Revd & Kintbury Manse & Vestryman (unspecified) \\
Goddard, Richard & Templeton Farm & Vestryman (unspecified) \\
Hayward, Thomas & Inkpen & Not known \\
Smith, Hogan & Kintbury Holt & Overseer \\
Litten, Thomas & Hampstead & Vestryman (unspecified) \\
& Marshall & \\
Randall, Joseph & Hamstead Holt & Vestryman (unspecified) \\
Steven, John & Anvilles Farm & Vestryman (unspecified), at \\
& Titcomb & Hungerford \\
Webb, Frederick & & Vestryman, Guardian of the Poor \\
& on 30 March 1830 \\
Willes, John & Hungerford Park & Vestryman (unspecified), JP, \\
& & Hungerford \\
\hline
\end{tabular}

gave should be spent there. One wonders if, as substantial landowners and occupiers of farms in the surrounding area, it suited them to have the crowd as far as possible contained in the town and away from their homesteads.

So far, we have dealt with events which have already been described, to a degree, in the sources. ${ }^{67}$ But what of those who took part in them, either as protagonists or victims? It has already been noted that the crowd action at Kintbury appears to have been ignited by the maltreatment of a vagrant by the overseer, Hogan Smith, and we can take this line of enquiry further. From the parish records, we know that of the fourteen named targets of crowd action at Kintbury, eleven were vestrymen in the town itself, and at least two held specific parish offices at the time of Swing. Another, John Stevens, was a vestryman at Hungerford (Table I) ${ }^{68}$

On the one hand, this is to be expected: as we have seen, almost all of those targeted were substantial farmers or major landowners. But it also raises the possibility that they were targeted, not simply because of their

67. See, for example, Hobsbawm and Rudé, Captain Swing, pp. I37-I40; Chambers, Berkshire Machine Breakers, pp. 36-52.

68. Berkshire County Record Office [hereafter BCRO] $\mathrm{DP}_{78 / \mathrm{i} 8 / 4}$, Poor House and Vestry Minutes, I8 I6-I845, I6 April I830 and is December I830; BCRO, DP Minutes of the Special Standing Committee of the Vestry, I809-1834, 3 December I 830. 
status as employers or because they held positions of general influence in the locality, but because they were instrumental in formulating and administering parish policy. This in turn raises the question: how far was this likely to have been a direct influence on those who took part in the disturbances?

Again, from various official sources we know the names of sixty-seven members of the Kintbury crowd who may have been resident at Kintbury. ${ }^{69}$ Referring back to the Overseers Accounts, we can also say with a high degree of certainty that twenty-five, and possibly twenty-seven, of these received casual relief or weekly allowances from the parish in the twelve months before the disturbances. ${ }^{70}$ These range from John Annetts and Charles Cox, both of whom received only one casual payment over the year, to Edmund Steel, one of the crowd's spokesmen at the Town Hall, who received relief on twenty-six different occasions. Turning to the Hungerford Crowd, on the one hand we know a lot less about those who took part and what they did (we only have the brief details given at the Special Assizes at Reading), but on the other we can find out a lot more about their histories as paupers. As a result, we know of twenty-two men who were seriously implicated in the disturbances, and of these we can be fairly confident that ten received some kind of direct financial relief between I 823 and I 828 , the period covered by detailed parish records. ${ }^{71}$ Again, a range of experiences is evident, from William Chitter who received a single one-off payment of $9 \mathrm{~d}$ in 1825 , to Thomas Dance, who was given $£_{3} 84 \mathrm{~S}_{\mathrm{I}} \mathrm{I} / 2 \mathrm{~d}$ in casual payments, family allowances, and payments in lieu of work.

So what do these figures tell us about the possible links between poor labourers, parish relations, and participation in the disturbances? They tell us that a significant number of those involved in the disturbances are known to have been in direct receipt of monetary relief either in the period immediately before, or in the years leading up to, November I 830 - around 40 per cent of those at Kintbury, and nearly one-half of those we know of at Hungerford. But they also tell us that their experiences were very different, ranging from long-term dependence to the most casual contact with the overseers. With a different emphasis, of course, we could say that the figures suggest that between half and two-thirds of those who made up the Hungerford and Kintbury crowds did not have any direct financial dealings with the overseers immediately

69. BCRO, QSi 8/0I/I83I, List of Rioters Bound Over for Their Involvement in Disturbances at Kintbury, January I831; Calendar of Prisoners Committed to the Special Assizes, Reading, 27-28 December I830, cited in Chambers, Berkshire Machine Breakers, pp. 253-395.

70. BCRO, DP78/12/9, Kintbury Overseers' Accounts, I 829.

71. Calendar of Prisoners Committed to the Special Assizes, Reading, pp. 253-395; BCRO, DP7I/I2/I2\&I3, Hungerford Overseer's Accounts, I 823-I 828. 
before the disturbances, which is something of a surprise given what we know about the situation of agricultural labourers in the south of England after the French Wars. ${ }^{72}$ But there is one more vital element in the story of parish relations in these two places which has so far gone unmentioned.

It is true that most crowd activity around Kintbury and Hungerford related to issues surrounding the employment of agricultural labourers. But it is also true that a demand for money was made at every place where the crowd made its presence felt. Frederick Page (from whom we heard earlier) reported that "at each respectable House [the crowd demanded] money of the farmers who had a Machine - 2 sovereigns for every Machine - amongst others of whom money was thus demanded was the Revd J Fowle who gave them $£_{2}$ and some beer" ${ }^{73}$ Most historians have noted this phenomenon, which was widespread throughout the south central counties during the disturbances, and have linked it to the giving of "civility money" or the custom of "crying largesse" during other customary occasions. ${ }^{74}$ But around Hungerford (and, as I have demonstrated elsewhere, across Berkshire and Hampshire as a whole) most of these demands actually took the form of payment for work done, usually the smashing of a threshing machine, as Frederick Page suggests. ${ }^{75}$ At Joseph Randall's house, where the window was broken, the crowd was offered only $\mathfrak{E}_{\mathrm{I}}$ and someone was heard to remark, "they would not have it it is hard work breaking Machines" ${ }^{76}$

The fact that the leader of the Kintbury crowd, William Winterbourn, was described as its "Captain" is also relevant. ${ }^{77}$ Across the landscape of the disturbed counties, many (possibly even most) crowds had their appointed, or self appointed "Captains" (or, occasionally, "Generals”, and even the odd "Counsellor") mirroring the eponymous Captain Swing himself. ${ }^{78}$ What most historians have overlooked is the wider importance

72. For welfare in the south of England during the first third of the nineteenth century, see M. Blaug, "The Myth of the Old Poor Law and the Making of the New", Journal of Economic History, 23 (1963), pp. I I I-I 84; D.A. Baugh, "The Cost of Poor Relief in South-East England, 1790-I 834”, Economic History Review, 28 (1975), pp. 50-68; K. Williams, From Pauperism to Poverty (Oxford, I98I), pp. 43-5 I; S.A. King, Poverty and Welfare in England, I700-1850: A Regional Perspective (Manchester, 2000), ch. 6, pp. I4I-I80; S. Williams, "Poor Relief, Labourers' Households and Living Standards in Rural England c.1770-1834: A Bedfordshire Case Study", Economic History Review, 58 (2005), pp. 485-5 19.

73. TNA, $\mathrm{HO}_{52} / 6$, fo. 60.

74. Bushaway, By Rite, p. I32.

75. Jones, "Swing, Speenhamland and Rural Social Relations", pp. 276-277.

76. TNA, TS I I -849 , Bundle I.

77. Ibid.

78. P.D. Jones, "Captain Swing and Rural Popular Consciousness: Nineteenth-Century Southern English Social History in Context" (unpublished Ph.D. thesis, University of Southampton, 2003), p. 38 . 
of the informally appointed "Captains" in the working lives of many agricultural workers. Captains negotiated wages and conditions with farmers on behalf of those who laboured without the security of service: in effect, they were the unofficial leaders of unofficial work-gangs at the level of the parish or township. ${ }^{79}$ So in a sense, the issue of payment for what the crowd defined as work seems to have been part of a wider symbolic language that reflected the legitimacy, not only of their demands but of the very constitution of the crowd itself. But in the context of parish relations in Kintbury and Hungerford, the demand for payment for breaking machines had an even more striking and immediate resonance.

The fact is that by 1830 the agricultural labour market in both towns had been regulated, not by the free market, or even by a simple cartel of employers, but by the vestry. In Hungerford, for example, the parish was already employing paupers on the roads as early as 1784 , but shortly after the end of the French wars its role in the working lives of all labourers became much more substantial and systematic. On 20 October i 8 I 8, in response to rising unemployment and rocketing poor rates, the vestry passed a number of resolutions: first, "that no land occupier or inhabitant contributing to the Poor Rates do employ out parishioners \& that they agree to immediately discharge such as are not hired servants"; second, that a list of all parish labourers should be compiled, including details of who employed them, in order that "a fair and just proportion of labourers be proportioned to each inhabitant or pay master according to his rate"; and third, that "the price of labour be reduced [...] to 9s a week" - not relief, but the price of labour; and not just of those who were employed by the parish, but of all settled labourers. ${ }^{80}$ These measures were restated and reinforced again and again between I 818 and I830, and they were by no means unique to Hungerford. ${ }^{81}$ At Kintbury, a number of similar measures were adopted: unemployed men were set to grubbing in 1817 and sent to the gravel pit in 1822 , a roundsman system was formally established in 1823 , a list of all parish labourers and their employers was compiled in I829, and the wages of labour - not just relief - were regulated at various times from I 823 onwards. ${ }^{82}$

In other words, it is no exaggeration to suggest that from the end of the French wars to the outbreak of the disturbances in 1830 , the parish authorities of Hungerford and Kintbury took on, not only the role of central labour exchange for agricultural labourers, but de facto that of their indirect employer, regulated who could be employed, by whom, and even the wages they were to receive. In addition, although we do not have

79. Ibid., p. 39 .

80. BCRO, DP 7 I $/ 8 / 3$, Hungerford Vestry Minutes, 6 June 1784, 20 October I 8 I 8.

81. Jones, "Swing, Speenhamland and Rural Social Relations", pp. 278, 284.

82. BCRO, $\mathrm{DP}_{78 / 18 / 4}$, Kintbury Vestry Minutes, I 8 January I 817 , I3 September 1822, 2I January I 823, 23 May I 823, 24 November I 829. 
a list of precisely who was being employed directly by the parish prior to i 830 , for Hungerford at least we know that the amount spent by the parish on "men out of employ" almost trebled between I 825 and I 828 . Hardly surprising, then, that labourers found it impossible to make a clear distinction between the issues of employment, entitlement to relief, and the obligations of their social superiors. After all, in Hungerford and Kintbury the roles of parish employer, parish official, and, in extremis, local charitable benefactor had become hopelessly entangled by 830 .

In other words, the protocols, the methods, and the very language (not least the "body language") of the Kintbury and Hungerford crowds really only make sense when we start to uncover the long-term social and economic trends that gave rise to them in the locality, and the relationships - between employer and employed, and between the vestry and the labouring poor - which were specific (though not exclusive) to this particular place and time. Of course, it goes without saying that many of these long-term trends were shared across the parishes and townships affected in 1830 and $183 \mathrm{I}$; nonetheless, it is important to bear in mind that each locality was host to its own small drama within the larger performance of the disturbances as they swept across southern England, and that both sides in the negotiating process were anxious to keep it that way.

"Swing" was not a movement of the labouring poor in the way implied by historians, and neither was it initiated, orchestrated, or organized by outsiders or fifth columnists as many contemporaries seemed determined that it should be. Instead, it was the aggregate response of many thousands of small "movements", made up of many thousands more labourers and their sympathizers, whose only organizing principle was the desire to see the restitution of "just", "fair" (and even "natural") relations between all sides in the social compact at the level of the parish and the workplace. While this may seem a small enough return to those who view their actions from the heights of posterity, we would do well to recall that it was sufficient reason for those many thousands of ordinary men and women, acting with no protection save that of custom and a collective belief in the justice of their demands, to put their lives, and their livelihoods, at risk.

It is also important to remember that protesters simply would not have exposed themselves in such an obviously dangerous way had they not had at least a reasonable expectation that their grievances would be heard and their demands met. Protagonists on both sides of the vestry table agreed that things could not go on as they were, and most - whether landowner, farmer, vestryman or labourer - were determined that solutions should be found locally. The Revd Fowle of Kintbury was a living example of this acting as he did, in his combined capacity as incumbent, magistrate and vestryman, as an intermediary between labourers, their employers and the vestry. As the chief negotiator with the labourers, he was able to secure 
both their demands, and their agreement to cease the disturbances, and appeared equally satisfied to have done both. Immediately following the meeting in the Town Hall at Hungerford, he reported to Charles Dundas:

$[\ldots]$ the terms required and acceded to were 12 shillings a week for a man wife $\&$ three children, \& the price of a gallon loaf for every child above three - These terms were acceded to by the Gentlemen as far as they could be, they were to be recommended for adoption to the Farmers - I hope they will accede to them. I am in momentary expectation of being sent for by the Kintbury Men who are returned or just returning to the village. I cannot of course try to beat them down to a lower price.

In a postscript, he added: "I have just met the men - I [agreed] the same terms which had been agreed at Hungerford and told them that as far as was in my power I would endeavour to persuade the Farmers to agree to them. The men gave three cheers and expressed themselves perfectly satisfied." ${ }_{3}$

\section{CONCLUSION}

In I969, Hobsbawm and Rudé described the disturbances of I 830 as the work of the "pre-political" poor, whose "ideological resources" consisted of "the belief in the rights of poor men by custom". ${ }^{84}$ It is a perspective that has dominated the historiography ever since. As we have seen, they were at least partially right: the protesters at Hungerford and Kintbury were certainly informed by custom, and even more so by the specific local conditions (including parish relations) that formed the backdrop to their actions. But is it fair to imply that this marked them out as "pre-political" and ideologically primitive?

In the introduction, I suggested that this kind of approach is inevitable when one seeks to identify, a priori, a "movement" of agricultural labourers, an organizing principle that gives the disturbances coherence as a whole, when evidence of no such "movement" can be found in the sources. There is something of the straw man in this, and in section I above he was identified as Captain Swing himself, a mythic figure invented in the lanes and alleys around Dover but perpetuated and given substance in the public imagination by a combination of pre-Reform panic and sensational reporting. It might be expected that the special commissions set up to deal with the perpetrators of the disturbances would have laid Swing to rest once and for all: as Hobsbawm and Rudés figures demonstrate, those prosecuted were overwhelmingly agricultural labourers, with a sprinkling of local craftsmen and shopkeepers - there

83. TNA, $\mathrm{HO}_{52} / 6$, fo. 45 .

84. Hobsbawm and Rudé, Captain Swing, p. 43. 
was not an agitator or provocateur in sight. ${ }^{85}$ Yet by the time the Commissions had finished their work, Swing was too potent a figure, and was far too notorious, simply to disappear from view.

In I 83 I he wrote his first pamphlet, a Radical rationale for the disturbances ghosted by Thomas Carlile. ${ }^{86}$ Shortly afterwards he penned another, a direct rebuttal of the first which, from its tone, could easily have been the handiwork of Hannah More: "I have sold myself to the Devil", it concluded, "I am his property; and so are those who teach you to deny your God; and so will you soon be if you listen to the blasphemous words of those [...] who would betray your souls". ${ }^{87}$ In the following years, up to Reform and beyond, Swing appeared many times in the press and in popular culture as hero or villain, depending on the viewpoint of the author. In April I83 I, he appeared in Hetherington's Poor Man's Guardian as

Jack Swing, the Greatest Reformer,

The fellow what burns all the hay

His reasons got warmer and warmer,

Till the slaves of corruption gave way. ${ }^{88}$

By I 834, he was heard to be in conversation with another well-known popular cultural icon, Jone O'Grinfilt, “on the burning of both Houses of Parliament", in which he was vocal in his opposition to the "National Debt" and new taxation, which "caused us all bond slaves to be". ${ }^{89}$ By I 840, the Labourers' Friend Magazine was calling him a "predial Chartist" in its campaign to raise labourers' wages. ${ }^{90}$

If his longevity is understandable in the context of pre- and postReform England, it is somewhat less so among historians assessing the genesis and impact of the disturbances. Except, of course, that the figure of "Swing", no matter how clearly a rhetorical construction of others than protesting labourers, provides them with a historically valid metonymical figure upon which they can flesh out the bare bones of a "movement" they assume to have taken place. Yet even those contemporaries who opposed Swing most directly acknowledged that "the stories about

85 . The proportion of agricultural labourers prosecuted in each county for "riot", "robbery" and their part in other assorted crowd actions ranged from 70 per cent to 95 per cent, according to their figures; ibid., p. 245 .

86. R. Carlile, Life and History of Swing, The Kent Rick Burner, Written by Himself (London, I 83 I).

87. Anon., The Genuine Life of Mr Francis Swing (London, [1831 ?]).

88. Poor Man's Guardian, 2 April I 83 I.

89. "Dialogue and Song, between Captain Swing and Joan O'Greefield [sic], on the Burning of Both Houses of Parliament" (n.d., [1 834?]), Oldham Public Library Local History Collection. 90. The Labourers' Friend Magazine, for Disseminating Information on the Advantages of Allotments of Land to the Labouring Classes (London, 1840), p. 54. 
strangers in gigs and [...] fire-balls" were a complete fabrication, and that " $[t]$ he culprit has [invariably] been a servant of the sufferer or a person living near to him, acting under some motive of revenge" - a clear echo of Cobbett's assessment of Swing the arsonist's true identity. ${ }^{9 \mathrm{I}}$ Which brings us full circle, back to the cottages, barns and vestry rooms of rural England.

If the Police Officer for the County Fire Office in London could agree with William Cobbett that a deterioration in local social relations was the crucial factor in mobilizing individuals and communities against employers and landlords, then who are we to disagree? In fact, Cobbett's assertion that "I should be more afraid of the vengeful feelings of one single labourer, whose son or brother I had caused to be imprisoned or severely dealt with for poaching, than I should be of [...] all the discontented spirits in London", ${ }^{92}$ finds a surprisingly direct parallel in the case of the Kintbury and Hungerford disturbances. Frederick Page, correspondent to the Home Office, remarked pointedly that "Kintbury \& Hungerford are seated near quiet preserves - there are many poachers, and not a little indignation was expressed by the Laborers there against the severity of the Game Laws \& the frequent commitments", and one of the leaders of the Hungerford delegation at the Town Hall, William Oakley, was heard to remark pointedly that "As for Old Forde of Kintbury he always kept Reading Gaol supplied with Poachers when he could have $\mathcal{E}_{2}$ apiece for them if it had not been for that he would have been in the workhouse long ago". ${ }^{3}$ Clearly, these were local concerns, relating to specific local social relations and, during the disturbances, played out in a self-consciously local context: the "procession" of the Kintbury crowd around the properties of the great and the good in the village graphically illustrates this. Nonetheless, despite the central thesis that there was no general "movement" behind the events of r830, still there is no denying that "Swing" was more than the sum of its parts.

Hobsbawm and Rudé, echoing contemporaries, spoke of the "contagion" of arson and protest to describe the way that the disturbances spread from parish to parish, ${ }^{94}$ and once again at Kintbury there is evidence that some members of the crowd sought to extend their influence beyond the immediate locality, having been "persuaded" by labourers from nearby parishes to lend their support to demands for similar wage settlements. ${ }^{95}$ Yet the more sinister reports, that they were intending to go

91. "Report to the Police Officer for the County Fire Office, London", cited in Hobsbawm and Rudé, Captain Swing, p. 240.

92. Ibid., p. 30 .

93. TNA, $\mathrm{HO}_{52} / 6$, fo. 27; TNA, ASSI 6-I, Part 3.

94. Hobsbawm and Rudé, Captain Swing, pp. 2 I 3-2 I4.

95. TNA, $\mathrm{HO}_{52} / 6$, fo. 5 I. 
from Hungerford Town Hall to Newbury as part of a general movement to set wages in the county and beyond, proved to be false, and across the landscape of Swing there is little or no evidence of crowds seeking to move beyond their extended locality en masse. ${ }^{96}$

Perhaps the best way of visualizing the progress of the disturbances is as a series of discrete moments of impact, like pebbles in a pond, each specifically meaningful within its own locality, but creating overlapping ripples that had a marginal impact on other localities and other moments of impact. In this way, the disturbances formed a kind of "meta-movement", a series of events coherent and tangentially connected in terms of their concerns and the manner of their progress, but having no guiding principle or special end outside the localities where they occurred. Surely it is clear by now that the only way to understand them properly is through more local studies at the level of the parish and the township such as the one presented here; indeed, it is clear enough that Richard Cobb's rallying cry, "and so to Lower Hardres", can no longer go unheeded. ${ }^{97}$

Identifying such a "meta-movement" for Swing, though, is very different from falling back on the default position that its protagonists were "pre-political" or archaic in their world-view. Rather, it is to assert that those who took part in the disturbances (or committed acts of arson) selfconsciously and deliberately sought to contain them within the locality. Labourers, no less than local landowners and farmers, had their sphere of influence, and it was here that they sought redress for their many grievances. In the final analysis, when taken as a whole the agrarian disturbances of 1830 were an attempt to reaffirm and reinforce traditional social and economic relationships in the locality that were (to a greater or lesser extent) shared across the whole of southern England, and that had at their heart the life of each parish and the operation of the vestry.

I have argued elsewhere that following the French wars the local and statutory measures taken to cut the spiralling costs of relief had a significant and possibly decisive effect on those relationships. ${ }^{9}$ Yet the patchwork of measures taken by parishes in central southern England in response to increasing un- and underemployment had the paradoxical effect of entangling parishes still further in the lives of labouring families, and (by default) of reinforcing the principle of local obligation and mutual dependence. For the labourers of south-central England, the key to this sense of entanglement is that, insofar as it provided a form of rudimentary (and, by I 830, mostly inadequate) social security, settlement in the parish was not only the measure of an individual's right to relief but (for day

96. TNA, $\mathrm{HO}_{52} / 6$, fo. 27.

97. R. Cobb, “A Very English Rising”, Times Literary Supplement, i September 1969.

98. Jones, "Swing, Speenhamland and Rural Social Relations", pp. 279-280, 284-287. 
labourers at least) their right to work. And, though commentators and historians may have had difficulty in conceptualizing it, this was clearly something that labourers felt was worth taking considerable personal risks to safeguard.

To paraphrase Jeanette Neeson's assessment of the mentalité of commoners, under the system of parochial and employment relations of the early-I 800 s, labourers "lived well enough for themselves, but invisibly and poorly in the eyes of outsiders", 99 and by 1830 they were prepared to do whatever it took to ensure that they could continue to "live well enough" under this intricate and precarious system. In the words of John Pearse (one of the gentlemen who spoke to the delegates at the Town Hall, who had not only been targeted by the Hungerford crowd but had been a member of the Posse Comitatus raised to hunt them down):

I lament that they should have obtained an increase of wages by such violent means but $[\ldots]$ they never would have got it without $[\ldots]$. I never saw so much happiness as has been produced by this change. It is a great step from $7 \mathrm{~s}$. or $8 \mathrm{~s}$. to Ios. - more than they ever expected to receive but not more than meets their wants. ${ }^{100}$

99. J.M. Neeson, Commoners: Common Right, Enclosure and Social Change in England, I700-I820 (Cambridge, I993), p. 4I.

І००. TNA, $\mathrm{HO}_{52} / 6$, fo. I4. 